\title{
VIRTUAL ORGANIZATIONS AND THE CULTURAL DIMENSION: ORGANIZATION RITES IN THE CONSOLIDATION OF TELEWORK
}

\author{
Simone Ghisi Feuerschütte \\ PPGEP/UFSC-sgf@floripa.com.br \\ Maria Rita Pimenta Rolim \\ PPGEP/UFSC-pimenta@floripa.com.br
}

BRAZIL

\begin{abstract}
The virtual organizacionais are constituted in a business strategy that dinamize the interaction with the consumer through the substitution of the physical presence by the technologies of information and communication. The virtual organizations are rendered with the implantation of the telework, a practice that adopts the technologies of information as possibility for the work is accomplished at a distance of the place where it would be executed traditionally. In this article, is intended the institution of values as innovation, flexibility, trust and team spirit to consolidate the practice of the telework in virtual organizations. It is suggested the development of some organizing rites that can translate those values requested for the effective introduction of the telework.
\end{abstract}

\section{INTRODUCTION}

A highly competitive environment has required of organizations a reformulation of their strategies and operational structures, presenting itself as a challenge to be dealt with in exchange of efficient outcomes to guarantee the organizational survival. The structural dimensions and the management models are reoriented towards the flexibility of processes, to follow systematically these environmental requirements which have become more and more demanding and dynamic.

Among the strategies for dealing with environmental competitivity we can highlight the introduction of new organizational forms, based not only on the implementation of more flexible structures but also in the appropriation of technologies that will characterize the typology and the predominant functions in an organization.

In a scenario of dynamic competition, virtual organizations emerge, recognized as a strategic tool that intensely utilizes communication and information technologies to generate new deals, focusing on the improvement of performance (Goldman, Nagel, Preiss, 1995; Venkatraman e Henderson, 1998). With this perspective, virtuality becomes an "organizational dimension, a rational strategy 
applicable to all organizations and not as a distinct organizational structure" (Steil and Barcia, 1999a).

In a historical moment instituted as the 'information era', the virtuality of organizations can be considered as a competitive differential, while it dynamizes interaction with the client meeting his real needs and interests. Venkatraman e Henderson (1998) highlight that the degree of virtuality of an organization is in the intensity it substitutes the physical presence by information and communication technologies to interact and make business with external and internal clients.

On the other hand, in the internal context of organizations this model based on such technologies may modify or break through some classical standards of the structural configuration, such as the process of communication, the hierarchical arrangements, the authority systems, norms and regulations, typical of bureaucratic models (Weber (1963) apud Campos, 1978). The virtual model of organizations presupposes a reduction of communication distances, that is carried out without the intervention of intermediaries, through reduction of the levels of hierarchy, the changes in the division of work and the flexibility in the formal patterns of the company. Trought, a configuration basead on the web is established which interactions have as their main characteristics interdependence and cooperation among members who seek to improve the results of the company through agile, flexible and integrating practices (Cohen, 1995).

This structural configuration of virtual organizations affect intensivelly the relations among the organization members, considering the organizational structure as an articulation between the formal arrangement and the interaction patterns (Ranson, Hinings and Greenwood, 1980). More evidence is given to the fact that the institution of a model based on networks implies in a reformulation of concepts and organizational values, besides the review of functioning mechanisms of the company itself.

The solidification of this kind of organization has been established through the implementation of telework, an innovating practice as far as the management model that suggests the analysis of the interactions design and the institution and the sharing of new meanings among members. This article analyzes some aspects of the organizational culture that establishes itself with the implementation of telework, highlighting the importance of instituting values that may consolidate it as an effective strategy of virtual organizations. Therefore, there is an attempt to approach the basic concepts of telework and of the organizational culture, considered as one of the fundamental subjective dimensions for the effectiveness of its implementation. In conclusion, we propose alternatives for the consolidation of values related to telework through the institution and development of organizational rites that, as far as systematized cultural practices, may contribute to the effective functioning of virtual organizations.

\section{TELEWORK: THE STRATEGIC FOCUS OF VIRTUAL ORGANIZATIONS}

The virtualization of companies phenomenon prescribes a new form of work organization - the telework - proposing a differentiated definition as space and time is concerned when it occurs. According to the definition of European Telework on Line (1998), this organizational practice presupposes the use of information 
technology as a possibility for the work to be made away from where the results are necessary, or distant from the place it would be traditionally executed. For this reason, it is possible to conclude that telework is configured as a flexible organizational practice, once it allows the reformulation of rigid pre-established standards for production, resulting in changes for workers as well as in the organizational processes.

Telework has been developed by organizations as a strategy focused on competitivity, following the market trends in terms of responding to the demands in an effective way. Studies and researchs in this area indicate that the implementation of this model may benefit the companies in terms of improvements in productivity and workers motivation, time reduction for answering to the customer and, consequently, in his degree of satisfaction with the organization, reduction of absenteeism and the rationalization of the usage of physical workspace (Kugelmass, 1996; Nilles, 1997; ETO, 1998).

Besides these facts, we perceive advantages from an individual point of view with the implementation of telework, such as enabling the workers to better conceal their personal and professional activities, reducing their commuting time, less expenses for clothes and the taking of better advantages of their productive potentialities according to their "biological clock", generating more dedication and efficiency in performance (Steil and Barcia, 1999b).

The already known benefits of telework, however, do not determine that some of its implications on organizational work are disregarded, clearly in relation to subjective dimensions. It is known that the implementation of this model interferes in various organizational aspects, highlighting structural configuration, understood under a dynamic perspective and generated according to permanent and successive interaction of organization members (Ranson, Hinings and Greenwood, 1980).

Under a more specific analysis, the development of actions based on telework also affects the definition of functions, tasks and the adequate profile of the worker, having in mind the establishment of new standards of work, performance and improved results for the organization. Steil and Barcia (1999b) mention that the implementation of telework in an organization corresponds to changes in its culture, once some new values must be reformulated so that the new organizational form is consolidated.

Problems with management and control, communication and integration among teleworkers, interpersonal relationships and even associated to the introduction and use of the new technologies, are identified in organizations that adopted telework as a strategic tool (Andreassi, 1997; Trope, 1999). In fact, it is understood that such problems are related to the cultural standards necessary to the consolidation of telework, which importance and reference are not always admitted or observed.

Generally, the cultural aspects are rescued when the organizational actions result in unacceptable actions and the agents identify in the subjective dimension of the organization, as the culture, the sources of problems and resistance related to the proposal of change (Feuerschütte, 1996). Given this difficulties, it is highlighted that the strengthening of the organizational culture, given the institution of values based on the innovation, confidence in sharing, team spirit and on a solid and alert leadership to the process of telework, may contribute to its effective implementation while a strategy of flexibilization of the organizations. 
The highlighted issues on elements that interfere in the process of organizational virtualization, especially related to telework, point out a necessity of not limiting the analysis to visible or explicit aspects in the context where it is developed. It is necessary to observe the subjective dimension of the workings of the organization that may interfere in the process so that the reality in which the model is to be implemented is known, enabling the possible definition of viable and effective realization of actions and, consequently, reach success with its accomplishment.

In the next topic, some theoretical contributions on organizational culture with the purpose of helping the analysis and the understanding of the resulting phenomenon of the implementation of telework in the organizations.

\section{ORGANIZATIONAL CULTURE: A SUBJECTIVE DIMENSION IN THE STUDY OF VIRTUAL ORGANIZATIONS}

The evolution of organizational culture concepts is associated, mainly, to the recognition of the limitations of the presupposed and the methods traditionally adopted to a more complex analysis of the organizations. The restriction of the mechanic paradigms to interpret the most subjective phenomenon of the organization made the scholars of the area adopt new approaches on the understanding of this reality and its work.

Linda Smircich (1983) identifies two main trends of scholars who study organizational culture: the ones that contemplate those that define it as organizational variable -- something the organization has - and the one that includes the authors who visualize culture as a metaphoric root - something the organization is.

As a variable, culture can be compared to other organizational dimensions, such as structure and technology, being approached while strategy oriented to performance, satisfaction and efficiency of the organization. Once under a perspective of metaphor, culture is analyzed from the interpretation of the elements and the symbolic meanings relevant to the comprehension of the organizational phenomenon.

The research based on the cultural metaphor reveals a universe created by collective action of the organization members and kept by means of meaning standards shared among them. Thus, the structures - normative systems, of reward and communication - the symbols, myths and rites adopted in the organizations reflect the values and the beliefs implicit in its culture and disseminated in all organizational levels. Such symbolic elements explain, many times, the actions and reactions of members due to certain practices implemented in the organization.

In this perspective, it is possible to define culture as a set of basic presuppositions, as values and beliefs, that characterize and orient the actions of organization members, reflecting in the configuration of the structure and the organizational processes (Feuerschütte, 1996). These presuppositions are systematically shared among people through of its interactions and result, according to Schein (1984), from the learning generated by collective experience of success in the organization. 
Considering that the culture presupposed is built through a process of group learning we see, then, that its formation is related to different interpretations that individuals make about the facts that occur around them, according to the values they share among themselves and which permeate their objective and their conduct in the organization. Values are preference standards rationalized and shared among members or among groups in the organization, in terms of what is wanted as procedures to be followed and results to be achieved (Beyer, 1981; Enz, 1986, 1988). They are considered the essence of organizational culture, that is, the elements that translate "the definitions concerning what is important for the organization to be successful" (Freitas, 1991, p. 18).

The values, while subjective meanings, may be expressed in different ways, translating the symbolic universe of the organizations, must be communicated and consolidated among members through tangible means (Trice and Beyer apud Fleury, 1989). In that sense, they can be disseminated through means of cultural elements such as rites, rituals, ceremonies, myths, symbols, forms of communication (language and resources) and physical environment (Schein, 1984; Fleury, 1989; Freitas, 1991).

For Trice and Beyer (apud Fleury, 1989; Freitas 1991) the rites are constituted in privileged elements for the interpretation of the organizational culture. They are defined as a planned set of activities relatively systematized, that combine various forms of cultural expression, like gestures, language, ritualized behavior and symbols with the purpose of generating results and practical consequences suitable to the occasion. A special highlight for this cultural elements is justified by its applicability in changing situations that presuppose the consolidation of new organizational values. It is known that, when innovations or implementations occur in technology, in structure or in the management models and work process, subjective aspects of the organization are affected. It is believed that cultural rites may be established as means of expression of new organizational values and very clearly in virtual organizations that are developing telework.

Although this practice is being adopted, more and more, as a strategy for the flexibilization of the activities of the companies (Kugelmass, 1996; Nilles, 1997), cultural interference is also known as a result of its implementation. The efficacy of telework, besides being connected to standards of technology and structure, is conditioned to the consolidation of an organizational culture founded on values appropriate to basic demands and specifications of the model. This way, we try sequentially to identify some values considered fundamental to the consolidation of telework culture in virtualized organizations suggesting as an alternative the development of cultural rites for the consolidation of such values.

\section{TELEWORK AND THE CULTURAL DIMENSION: CONTRIBUITION TO CONSOLIDATE VALUES IN THE VIRTUAL ORGANIZATION}

In an atmosphere of the implementation of models that innovate terms in organizations like telework, some standards have to be established to support the developed practiced in the sense that objectives are achieved. In the cultural perspective the implementation of telework in virtual organizations demands an 
approach to the main values of the model permitting, later on, a preview of collective practice that helps its consolidation as a typical element of the organizational culture.

Telework involves a big change in the understanding of the nature and form which the work process develops. Associated to that, new conceptions or values to orient organizational interactions must be considered. In this sense, we try to find some references as for the implementation and development of telework.

To begin with, the apprehension of the objectives of implementation of a new modality of work is basic for the members to be able to adopt values based on technology innovations and typical telework management forms. Tyrell (1995) reinforce that the already tecnolygies disponibles to execute the inovation model (email, telnet, teleconferences) can be used to transmit information about the organization, its mission, principles and its working forms.

In this perspective, it is possible to rescue the concept of distance as a fundament to the proposal of shared learning of the telework principles, once it is constituted in a construct that is not only applicable to physical-space positions, but involves other aspects of the relations among teleworkers (Raghuram et al, 1996). It is known that physical proximity at workspace does not, necessarily, imply in integration and sharing of the company's objectives.

Another aspect to be approached as a value for this strategic practice of the organization is team work, through which members recognize they cannot orient their actions and conduct according to the limits of their individual interests or needs. Telework demands from its workers a strong dose of confidence, loyalty and collaboration, so as to install a collective comprehension about the team - group potential is able to develop in relation to objectives and organizational results. Greiner and Metes (1997) affirm that when the workers consolidate these standards of team work, the workers begin to understand that recognition and recompense are based on values the team creates and not on individual activities of each member.

The preference for "team telework" as it is stated allows us to report Schein (1984) concept about the formation of organizational culture, that occurs through members collective learning when they get involved in searching for solutions for the work process. The success of their decision about strategies to be adopted in the development of telework will certainly mean the consolidation of values that will contribute to the legitimacy and efficacy of the process in the organization and, therefore, for the consolidation of a telework culture. This consolidation can be proposed through the creation and development of systematic activities as cultural rites, that tend to translate, through symbolic schemes, the values demanded for the effective implementation of telework.

Considering some implications of the cultural nature about the operation of telework, it is pointed out that some practices related to the rites presented by Tryce and Beyer (apud Fleury, 1989) as alternatives to organizations that develop telework.

\section{Passing rites}

The joining of new teleworkers through participation in programs that present, in a wide form, the context and the evolution of the process of organizational innovation. The inclusion of new members must also preview forms of presencial contacts to treat interpersonal relations and group integration. 
The activity changes cannot come before successive training to adapt to the new work process, to the new technologies and behavior rules according to the model of work. In these opportunities the sharing of knowledge is verified, findings and common difficulty, consolidating group values and confidence among members.

\section{Renovation rites}

The making of forums, seminaries, discussion meetings, planning and review of actions related to the work practice, with the participation of the people involved, allows the improvement of activities, reinforcement to each one's role in the process, besides enabling the consolidation of purposes and planned objectives for the organization to operate in the mentioned model. These activities are made of member's collective sites, as the problems of organizational nature are identified and that have to be resolved through shared search for solutions.

\section{Integration rites}

The occurrence of difficulties in the relationship among the involved in the implementation of telework, due to the new characteristics of the process, affect meaningfully the perception and the values shared related to the organizational work. Preconceived postures are observed in this sense as for teleworkers, isolation situations of those in the program, besides the physical and emotional stress (Nilles, 1997; ETO, 1998; Davies, 1995).

The approach of organizational culture in view of this context can be the implementation of systematic rites focused on the social integration of the participants, through meetings that stimulate personal contact, interaction and emotional support reinforcing the importance of each member for the success of the implemented model. The use of technological resources to disseminate support messages to the group for their contribution to the process is also a mechanism of consolidation of values inherent to the practice of telework. For example, technologies such as videoconference, teleconference, groupware (chats) as strategic resources for the implementation of rites and the dissemination of telework values. The virtual communities' creation by means of the Internet is another consolidation alternative of global values, related to the interests or their users' specific needs. Such communities establish their cooperation and collaboration rites, from adoption of own language to the subjection of specific rules for the entrance of their members.

\section{CONCLUSIONS}

This work tried to show the relevance of considering the subjective dimension of organizational culture as for the implementation of models or innovating process in the work of organizations, such as virtual organizations and telework.

Considering that organizational culture results from the sharing of members around objectives and practice of the organization, it is understood that all changes or innovations are only effective when there is a consolidation of common values that sustain the purposes and the directions of actions. This way, it is believed that the approach on cultural elements becomes fundamental to the success of a new organizational practice such as telework.

It is understood that for the efficacy of all practices of this nature, it is formerly necessary to identify cultural aspects of the organization as a whole, associated to 
the analyses of its other dimensions, for subsequently analyze the implicit character of each organizational group. In this manner it is possible to trace the cultural characteristics of the environment where telework is being implemented, to define aspects considered functional or inoperative to the purposes connected to the strategy adopted as an answer to the environmental demands.

It is worth highlighting, that the activities described, under the form of organizational rites, intend to serve as suggestion to practices that will contribute to the institution of telework in virtual organizations or even in companies that intend to institute it as a competitive strategy. The implementation of rites, for its cultural characteristics and symbolic practice, will certainly favor the consolidation of necessary values to the legitimization of this innovating model in the organizations.

\section{REFERENCES}

1. Andreassi, Tales. Virtualização das organizações: o caso do teletrabalho em uma consuloria. Revista de Administração da USP, v.32, n.4, p.77-83, out.dez 1997.

2. Beyer, Janice M. Ideologies, values and decision make organizations. In Handbook of organizational design, Nystron, Paul C. Starbuck, William H. New York: Oxford University Press, 1981. 2.v.

3. Campos, Edmundo. Sociologia da burocracia. 4 ed. Rio de Janeiro: Zahar Editores, 1978.

4. Cohen, Susan G. A nova organização por equipes e o trabalho de equipe. In Organizando para competir no futuro: estratégia para gerenciar o futuro das organizaçōes. Galbraith, J. et al. São Paulo: MAKRON Books, 1995.

5. Enz, Cathy. Power and shared values in the corporate culture. Ann Arbor: Umi Research Press, 1986.

6. The role of value congruity intraorganizational power. Administrative Science Quaterly, v.33., n.2, p. 284-304, june 1988.

7. European Telework OnLine (ETO). <http://www.eto.org.uk/faq/defin_tw.htm>

8. Feuerschütte, Simone G. Cultura organizacional e dependências de poder: a mudança estrutural no Centro de Informática e Automação do Estado de Santa Catarina S.A. - CIASC. Florianópolis, 1996. Dissertação (Mestrado em Administração) - Universidade Federal de Santa Catarina, 1996.

9. Fleury, Maria Tereza Leme. O desvendar da cultura de uma organização: uma discussão metodológica. In Cultura e poder nas organizaçðes. Fleury MTL, Fischer RM (coords.). São Paulo: Atlas, 1989.

10. Freitas, Maria Ester de. Cultura organizacional: formação, tipologias e impacto. São Paulo: Makron, MacGrall-Hill, 1991.

11. Goldman S, Nagel R., Preiss K. Agile competitors. Concorrência e organizaç̃̃es virtuais. São Paulo: Érica, 1995.

12. Greiner R., Metes G. Going virtual. Upper Saddle River: Prentice-Hall, 1995

13. Kugelmass, Joel. Teletrabalho. São Paulo: Atlas, 1996.

14. Nilles, J. Fazendo do teletrabalho uma realidade. São Paulo: Futura, 1997.

15. Raghuram S, Wiesenfeld B, Garud R. Distance and propinquity: a new way to conceptualize work, 1996.

16. Ranson S, Hinings B, Greenwood R. The structuring of organizational strutures. Administrative Science Quaterly, v.25, n.1., p.1-17, mar. 1980.

17. Schein, Edgar H. Coming to a new awareness of organizational culture. Sloan Management Rewiew, v.25, n.2, p.3-16, winter, 1984.

18. Smircich, Linda. Concepts of culture organizational analysis. Administrative Science Quaterly, v.28, n.3, p.339-358, sept. 1983.

19. Steil A, Barcia R. Aspectos estruturais das organizaç̃̃es virtuais. Submetido ao ENANPAD 99, Foz do Iguaçú, 1999a. (digitado)

20.

. Um modelo para análise da prontidão organizacional para implantação do teletrabalho. Submetido à Revista de Administração da USP, 1999b. (digitado)

21. Davies R, Tyrell MWD. Culture and interaction. Telecommuting Internet Conference, 1995.

22. Trope, Alberto. Organização virtual: impactos do teletrabalho nas organizaçð̃es. Rio de Janeiro: Qualitymark Ed., 1999.

23. Venkatraman N, Henderson J. Real strategies for vitual organizing. Sloan Management Review, v.40, n.1., p.33-48, Fall 1998. 